Jurnal ASPIKOM, Vol. 7, No. 1, January 2022, pp. 61-70

P-ISSN: 2087-0442, E-ISSN: 2548-8309

DOI: http://dx.doi.org/10.24329/aspikom.v7i1.1058

\title{
Public Attitudes towards the Government's Policy Communication in Preventing COVID-19
}

\author{
Abrar Adhani ${ }^{1}$, Akhyar Anshori ${ }^{2 *}$, Ananda Mahardika ${ }^{3}$ \\ ${ }^{1,2}$ Program Studi Ilmu Komunikasi, Universitas Muhammadiyah Sumatera Utara, Jalan \\ Kapten Mukhtar Basri No. 3 (20238), Sumatera Utara, Indonesia \\ ${ }^{3}$ Program Studi Administrasi Publik, Universitas Muhammadiyah Sumatera Utara, Jalan \\ Kapten Mukhtar Basri No. 3 (20238), Sumatera Utara, Indonesia \\ *Corresponding author, e-mail: abraradhani@umsu.ac.id
}

\begin{abstract}
The spread of COVID-19 in Indonesia needs the policy to overcome it, especially for the implemented communication. The government communicates that dealing with the spread of COVID-19 is a problem in society. The study is to find out how the public's response is related to the communication of government policies in preventing COVID-19. The approach of this study is quantitative, with data collection carried out through questionnaires for 400 respondents. The data obtained are analyzed using SPSS 25.0. The study finds that the government conducted communication crises dealing with the overcoming of COVID-19 to protect their policies from the reality that society's policies were not obeyed. This attitude happens due to the inconsistency of government officers and their conduct towards society. Related to the vaccination of COVID-19, the majority of society in Medan says they agree with the program to prevent the spread of COVID-19.
\end{abstract}

Keywords: COVID-19; Community Response; Government Policy; Policy Communication

\begin{abstract}
Abstrak
Penyebaran Covid-19 di Indonesia membutuhkan sebuah kebijakan dalam penanggulangannya khususnya terkait dengan bentuk komunikasi yang dilakukan. Komunikasi pemerintah dalam penanggulangan penyebaran covid-19 menjadi persoalan di masyarakat. Tujuan penelitian ini untuk mengetahui bagaimana respon masyarakat terkait dengan komunikasi kebijakan pemerintah dalam pencegahan covid-19. Pendekatan dalam penelitian ini melalui pendekatan kuantitatif dengan pengumpulan data dilakukan melalui kuesioner terhadap 400 orang responden. Data yang diperoleh selanjutnya di analisis dengan menggunakan alat bantu software SPSS 25.0 for windows. Hasil penelitian menemukan bahwa komunikasi krisis dalam penanggulangan Covid-19 yang dilakukan pemerintah melalui penerapan berbagai kebijakan, nyatanya tidak sepenuhnya dipatuhi dan dilaksanakan oleh masyarakat. Hal ini tidak terlepas dari inkonsistensi pernyataan pejabat publik dan tidak konsisten nya pelaksanaan kebijakan di tengah-tengah masyarakat. Terkait dengan kebijakan vaksinasi covid-19, mayoritas masyarakat Kota Medan menyatakan setuju atas program tersebut dalam upaya pencegahan penyebaran covid-19.
\end{abstract}

Kata Kunci: COVID-19; Respon Masyarakat; Kebijakan Pemerintah; Komunikasi Kebijakan 


\section{Introduction}

The communication process in policy-making is important, especially in a democratic country like Indonesia. It is impossible to determine policy without a communication process as a form of interaction and coordination between policymakers and the community's benefit (Kamil, 2018). Public communication principles, components, and functions need to be considered. The value of the communication process that occurs in an effort to build a constructive interaction between policy makers and the community is the main thing.

The rapid spread of Covid-19 in Indonesia requires a policy to overcome it. One of them is implementing the $5 \mathrm{M}$ policies, namely washing hands, wearing masks, maintaining distance, avoiding crowds, and reducing mobility (Rijal et al., 2021). The delivery of policies carried out by the government, in this case, related to the prevention of COVID-19, cannot be separated between restrictions on community activities and the individual basic needs of the community itself. Government communication will determine the community's attitude in implementing any existing policies. Vardavas et al. (2021) found that the community is very responsive to every action and policy from the government that communicates well and effectively through various communication channels.

This policy carried out by the Indonesian government, in fact, is not fully complied with by the Indonesian people. This can be seen from the various conflicts between the central government and local governments to respond to the spread of covid-19 (Juaningsih et al., 2020). There are differences in perceptions among the public regarding the impact of the spread of COVID-19, adding to the difficulties of implementing Covid-19 prevention policies in Indonesia (Limilia and Pratamawaty, 2020). Not to mention the fact that the government's communication conditions tend to be inconsistent in dealing with the spread of COVID-19 (Rengkung et al., 2021).

The pandemic condition requires the government to be sensitive in dealing with the crises. Crisis communication is the most important instrument in crisis management (Surahmat et al., 2021). Coombs and Holladay (2012) explain that crisis communication is the collection, processing, and dissemination of information that can be used to overcome a crisis. In this context, the government's crisis communication in an effort to prevent Covid-19 is a step in determining the policies implemented by the Indonesian government.

This can be seen from Windarsih's (2021) research which saw the differences in ways of dealing with COVID-19 between the government of the Republic of Indonesia and the regional government of Jakarta, which is the capital city of Indonesia. The study results found contradictory statements related to the Covid-19 prevention policy. One of them is related to the Covid-19 response policy in Jakarta, which some people translated as a policy taken in the politicization of policy. The role of communication during the Covid-19 crisis is very decisive in providing complete information and in accordance with the facts on the ground (Surahmat et al., 2021).

Statements made by the government, in this case, the president and ministers, and other related institutions, tend to become a subject of a joke in society. There is an impression that at the beginning of the COVID-19 pandemic that hit the world, the Indonesian government responded by throwing jokes that caused ridicule by the public (Sulistyowati and Hasanah, 2021). This can be seen from the release submitted by the Institute for Research, Education, Economic and Social Information (LP3ES) in April 2020, releasing information related to 37 government blunder statements in response to 
the spread of Covid-19. In fact, the policies and messages issued by the government during the early Covid-19 period were very supportive and guided the behavior of the community in understanding and being aware of Covid-19 (Reyes Bernard et al., 2021)

The people of Indonesia can still clearly remember these controversial statements. The person who made the statement is a public official who is very closely related to the handling of COVID-19 (Surahmat et al., 2021). Some of these statements include a joke by Coordinating Minister for Political, Legal, and Security Affairs Mahfud MD, who said that Coordinating Minister for the Economic Airlangga Hartarto said that Covid-19 did not enter Indonesia licensing was difficult. Alternatively, Indonesian vice president Ma'ruf Amin said that the coronavirus had left Indonesia because of the qunut prayer. These statements immediately colored every line of news, including on social media. There are abundant studies related to the public's response to COVID-19 and government policies in dealing with it, especially those based on social media (AbdAlrazaq et al., 2020; Boon-Itt and Skunkan, 2020; Chandrasekaran et al., 2020).

Government statements and policies that are not relevant to the prevention of COVID-19, in fact make people distrust various statements made by the government regarding Covid-19(Goeritman, 2021). Statements by public officials in Indonesia that are not in accordance with the facts about Covid-19 have added to the level of public distrust of the government (Mansoor, 2021). Moreover, this is exacerbated by the public's distrust of information conveyed by mass media and social media regarding the development of COVID-19 in Indonesia (Saleh et al., 2021). Among students, the actions taken in obtaining information through social media tend to be done selectively so that the information obtained can be sorted first before being forwarded (Junaedi and Sukmono, 2020).

The Indonesian government in dealing with Covid-19 should be able to act and behave and be responsible for the actions taken to ensure transparency and access to correct information for the public. (Beshi and Kaur, 2020). This article aims to see how the people's attitude of Medan City towards the communication of government policies in preventing Covid-19. The research questions to be answered are (1) what is the people's attitude of Medan City regarding government policies in Large-Scale Social Restrictions? and (2) what is the attitude of the people of Medan City towards the Covid-19 vaccination policy?

\section{Method}

This research was conducted through a positivist paradigm with quantitative research. Azwar (2011)emphasizes that quantitative analysis is on numerical data (numbers) which is processed by statistical methods. Neuman(2014)believes that theory is formed from a set of universally applicable laws, where numerical data is related to hypotheses. The method used in collecting data in this research is a survey method, Sugiyono(2018)states that survey research is a method used to obtain data that occurred in the past or present. Respondents are people of Medan City who are aged 17 years and over. The respondent's age threshold was determined because people aged 17 years and over were considered quite capable of responding to the research objectives. The total population in the study was 1,601,001 people, according to the Permanent Voters List in the 2020 Medan City Election (Muhardiansyah, 2020). This research was conducted in July 2021. Through the Slovin formula with a precision of 5\%, the total sample for this study was 400 people using the simple random sampling method. This means every member of the population has the opportunity to be a sample in this study. Data analysis 
was carried out descriptively through single table analysis using SPSS 25.0 software for windows.

Table 1. Statistics

\begin{tabular}{|c|c|c|c|c|c|c|c|}
\hline & & $\begin{array}{c}\text { The } \\
\text { policy of } \\
\text { closing } \\
\text { face-to- } \\
\text { face } \\
\text { learning } \\
\text { activities }\end{array}$ & $\begin{array}{l}\text { Policy on } \\
\text { limiting } \\
\text { worship } \\
\text { activities in } \\
\text { places of } \\
\text { worship }\end{array}$ & $\begin{array}{l}\text { Policy of } \\
\text { limiting } \\
\text { activities } \\
\text { in public } \\
\text { places }\end{array}$ & $\begin{array}{l}\text { Policy of } \\
\text { limiting } \\
\text { operating } \\
\text { hours of } \\
\text { public } \\
\text { places }\end{array}$ & $\begin{array}{c}\text { The policy } \\
\text { of limiting } \\
\text { the } \\
\text { operating } \\
\text { hours of } \\
\text { Food Stalls }\end{array}$ & $\begin{array}{c}\text { Vaccination } \\
\text { Policy }\end{array}$ \\
\hline \multirow[t]{2}{*}{$\mathrm{N}$} & Valid & 400 & 400 & 400 & 400 & 400 & 400 \\
\hline & missing & 0 & 0 & 0 & 0 & 0 & 0 \\
\hline mean & & 3.35 & 2.98 & 3.89 & 3.83 & 3.65 & 4.08 \\
\hline median & & 3.00 & 3.00 & 4.00 & 4.00 & 4.00 & 4.00 \\
\hline Mode & & 4 & 3 & 4 & 4 & 4 & 4 \\
\hline Sum & & 1340 & 1191 & 1555 & 1531 & 1461 & 1633 \\
\hline Percent & 25 & 3.00 & 2.00 & 4.00 & 3.00 & 3.00 & 4.00 \\
\hline \multirow[t]{2}{*}{ iles } & 50 & 3.00 & 3.00 & 4.00 & 4.00 & 4.00 & 4.00 \\
\hline & 75 & 4.00 & 4.00 & 4.00 & 4.00 & 4.00 & 5.00 \\
\hline
\end{tabular}

\section{Results and Discussion}

The results of the research on the attitude of the people of Medan City towards the communication of government policies in preventing Covid-19, the characteristics of the respondents can be seen in Table 2 .

Table 2. Characteristics of Respondents

\begin{tabular}{|c|c|c|c|}
\hline \multicolumn{2}{|c|}{ Characteristics } & \multirow{2}{*}{$\frac{\text { Amount }}{211}$} & \multirow{2}{*}{$\begin{array}{c}\text { Percentage } \\
52.75\end{array}$} \\
\hline \multirow{2}{*}{ Gender } & Man & & \\
\hline & Woman & 189 & 47.25 \\
\hline \multirow{6}{*}{ Age } & 17-20 Years & 101 & 25.25 \\
\hline & 21-30 Years & 131 & 32.75 \\
\hline & 31-40 Years & 62 & 15.50 \\
\hline & 41-50 Years & 62 & 15.50 \\
\hline & 51-60 Years & 32 & 8.00 \\
\hline & $>60$ Years & 12 & 3.00 \\
\hline \multirow{5}{*}{ Religion } & Islam & 364 & 91.00 \\
\hline & Protestant & 17 & 4.25 \\
\hline & Catholic & 12 & 3.00 \\
\hline & Buddha & 5 & 1.25 \\
\hline & Confucius & 2 & 0.50 \\
\hline \multirow{5}{*}{ Work } & Government employees & 17 & 4.25 \\
\hline & Employees of BUMN or BUMD & 13 & 3.25 \\
\hline & Teacher / Lecturer & 14 & 3.50 \\
\hline & Professionals (Doctors, Lawyers, Accountants) & 3 & 0.75 \\
\hline & Entrepreneur / Trader & 54 & 13.50 \\
\hline
\end{tabular}




\begin{tabular}{lcc}
\hline Private sector employee & 48 & 12.00 \\
\hline Transportation Service & 6 & 1.50 \\
\hline Work Not Permanent & 36 & 9.00 \\
\hline Still in School / College & 116 & 29,00 \\
\hline Housewife & 53 & 13.25 \\
\hline Does not work & 24 & 6.00 \\
\hline Other & 16 & 4.00
\end{tabular}

The study found that $91.00 \%$ of respondents had followed the development of Covid-19 since the beginning of this virus hitting the world. There are $41.75 \%$ of respondents who believe that people who have recovered from COVID-19 will be immune to Covid-19 infection. The massive spread of COVID-19 has made $91.00 \%$ of respondents very worried about this condition. In addition, there are $93.25 \%$ of respondents who are very vigilant about their daily activities to avoid the spread of COVID-19.

$72.75 \%$ of respondents think that coronavirus is the most dangerous virus to date. Even $70.00 \%$ of respondents believe that coronavirus is a deadly virus today. $76.50 \%$ of respondents stated that the transmission of Covid-19 was more likely to occur in the elderly and people with serious illnesses.

In terms of the increase in positive cases of Covid-19, $75.00 \%$ of respondents stated that this was the government's responsibility. Meanwhile, the implementation of the $5 \mathrm{M}$ concept based on the results of this study is not well adhered to and implemented by the community. Only about $48.50 \%$ of respondents apply the $5 \mathrm{M}$ pattern in their daily lives.

\section{Distribution of Public Attitudes Regarding Government Policies against Covid-19 Prevention}

Research on the attitude of the people of Medan City towards the communication of government policies in preventing Covid-19. This was carried out to see how the public's views related to several policies taken by the government towards efforts to hold the spread of COVID-19. Several government policies that are part of this research include; (1) The policy of closing face-to-face learning activities, (2) the policy of limiting worship activities in places of worship, (3) the policy of limiting activities in public places, (4) the policy of limiting the operating hours of public places, (5) the policy of limiting the place of hawker stalls /food, and (6) vaccination policy.

Table 3. Attitude Distribution Society against Government Policy Communication in Prevention of Covid-19

\begin{tabular}{lccccc}
\hline \multicolumn{1}{c}{ Category } & STS & TS & KS & S & SS \\
\hline Policy to Close Face-to-Face Learning Activities & 33 & 52 & 116 & 140 & 59 \\
Policy on Restriction of Worship Activities in Houses of & 58 & 75 & 120 & 112 & 35 \\
Worship & 11 & 17 & 68 & 214 & 90 \\
Policy on Restriction of Activities in Public Places & 15 & 18 & 69 & 217 & 81 \\
Public Places Operational Hours Restriction Policy & 19 & 27 & 104 & 174 & 76 \\
Policy on Restriction of Operational Hours for Food Shops & 9 & 9 & 65 & 174 & 143 \\
COVID-19 Vaccination Policy & & & & &
\end{tabular}


Regarding the policy of closing face-to-face learning activities, only $49.75 \%$ of respondents agreed that the policy was appropriate to implement to prevent the spread of COVID-19. This is inseparable from the level of concern for parents in the mentoring process when children take online learning. Some of these things are inseparable from the limited experience of parents in teaching (Suciati and Syafiq, 2021) and also parental anxiety about the child's condition, which makes it possible to experience academic stress because the online learning process is more likely to give children an excessive assignment burden (Muslim, 2020).

Meanwhile, related to the government's policy on limiting worship activities in places of worship, $63.25 \%$ of respondents stated that they disagreed with the policies carried out by the government. For the people of Indonesia, restricting worship activities in a place of worship for someone is the first policy that has been enacted. The issue of worship, which cannot be separated from the form of one's belief in the creator during the covid-19 pandemic, caused many community challenges regarding the implemented policies (Tobroni, 2020).

Meanwhile, for the policy of restricting activities in public places, $76.00 \%$ of respondents agree with implementing the policy. Likewise, with the policy of limiting the operating hours of public places, $74.50 \%$ of respondents agreed with this. The same thing is also related to the government's policy of limiting the operating hours of street food stalls or stalls during the covid-19 period, where $62.50 \%$ of respondents agree with the implementation of the policy. This restriction is, of course, an effort to overcome the spread of Covid-19, where shopping centers, public facilities, and food stalls or any stalls tend to provide freedom for everyone to interact directly, thus allowing Covid-19 to spread quickly. On the other hand, the limitation of operating hours is not in line with efforts to maintain economic conditions and the welfare of the people who make the stalls and snacks business as the foundation of their daily income (Tuwu et al., 2021).

Restrictions on activities in public places, restrictions on operating hours for public places, and restrictions on operating hours for food shops and stalls have a significant impact on the economic income of the community. In tight policies produced by the government, the community is required to deal with the condition of family financial expenditures, one of which is by looking for other sources of income (Kurniasih, 2020).

In terms of the government's vaccination policy for the Indonesian people, $79.25 \%$ of respondents agreed with the government's steps to carry out a vaccination program to prevent the spread of COVID-19. Even though at the beginning of the COVID-19 vaccination program, the government tends to find pros and cons in public acceptance (Hernikawati, 2021; Rachman et al., 2020). However, the research findings show a positive acceptance rate among the people of Medan City. The people of Medan City accept this vaccination program to prevent and reduce the impact of the spread of Covid-19.

The differences that occur in responding to various Indonesian government policies in dealing with COVID-19 cannot be separated from the actions taken by public officials in conveying information related to the spread of Covid-19. Research conducted by Goldstein and Wiedemann (2020) and Murphy et al. (2020) emphasizes that public trust in the government will encourage the level of community compliance in implementing every government policy. Also, public distrust in the government causes the public to be unprepared to comply with government policies to overcome COVID19 (Guglielmi et al., 2020). The results of this study also confirm the results of previous 
studies (e.g., Clark et al, 2020) related to public trust in the government, which is very small in complying with recommendations related to preventing the transmission of Covid-19, including the use of masks, maintaining distance, washing hands and staying at home.

Therefore, the policies implemented by the government can at least be demonstrated by consistent behavior and actions in their application to anticipate the spread of COVID-19. The actions and consistency taken by the government will raise the level of public trust in the government so that any policies were taken, especially regarding the prevention of Covid-19, will motivate the public to follow every recommendation from the government (Hafner-Fink and Uhan, 2021; Murphy et al., 2020). During the current crisis, the government and other public officials are the primary sources of information regarding preventing Covid-19 (Sood and Sharma, 2020; Sun et al., 2020). The information submitted must be in line with the actions taken, including applying sanctions for any community that violates it.

Like Coombs and Holladay (2012), crisis communication is an effort to collect, process, and convey information related to existing conditions. Public trust in the actions taken by the government in overcoming the spread of Covid-19 and the application of sanctions for each offender is expected to increase public understanding about awareness related to Covid-19. The awareness that arises from each community will positively impact efforts to prevent Covid-19 in the community. Cooperation between the government and the community in efforts to overcome Covid-19 will undoubtedly create obedient and responsible behavior in preventing the spread of Covid-19

\section{Conclusion}

Based on the results of research on the attitude of the people of Medan City towards government policy communication in preventing COVID-19, several conclusions can be drawn as follows, (1) Crisis communication in dealing with Covid19 carried out by the government through the implementation of various policies is, in fact, not fully complied with and implemented by the community. This is inseparable from the inconsistent statements of public officials and the inconsistent implementation of policies in the community, (2) The study found that there was resistance from the community towards the policy of closing face-to-face learning activities and the policy being implemented against the restriction of worship activities in houses of worship, (3) Regarding the COVID-19 vaccination program, the majority of the people of Medan City agreed to the program to prevent the spread of COVID-19.

Then, some suggestions that the author can give related the attitude of the people of Medan City towards the communication of government policies in preventing covid19, are as follows, (1) The people of Indonesia should always apply a clean and healthy lifestyle and always apply 5M in their daily activities, (2) The government is expected to issue effective, efficient, and consistent policies to anticipate the transmission of COVID-19 and begin to review policies related to being able to coexist with COVID19, (3) For further researchers, it is hoped that they will be able to develop the results of this research through critical approaches to develop communication activities, especially crisis communication and government communication in overcoming the existing social conditions of society. 


\section{Acknowledgments}

The author would like to thank the Chancellor of the University of Muhammadiyah North Sumatra, who has provided the most comprehensive opportunity for the author to conduct related studies on the attitude of the people of Medan City towards the communication of communication government policies in preventing COVID-19. The author also does not forget to thank everyone who has supported the research process and the writing of this scientific article. Hopefully, the results of this research can be useful for the development of science, especially communication science in crisis communication and governance.

\section{References}

Abd-Alrazaq, A., Alhuwail, D., Househ, M., Hai, M., dan Shah, Z. (2020). Top concerns of tweeters during the COVID-19 pandemic: A surveillance study. Journal of Medical Internet Research, 22(4), 1-9. https://doi.org/10.2196/19016

Azwar, S. (2011). Reliabilitas dan Validitas. Yogyakarta: Pustaka Pelajar.

Beshi, T. D., dan Kaur, R. (2020). Public Trust in Local Government: Explaining the Role of Good Governance Practices. Public Organization Review, 20(2), 337350. https://doi.org/10.1007/s11115-019-00444-6

Boon-Itt, S., dan Skunkan, Y. (2020). Public perception of the COVID-19 pandemic on twitter: Sentiment analysis and topic modeling study. JMIR Public Health and Surveillance, 6(4), 1-17. https://doi.org/10.2196/21978

Chandrasekaran, R., Mehta, V., Valkunde, T., dan Moustakas, E. (2020). Topics, Trends, and Sentiments of Tweets about the COVID-19 Pandemic: Temporal Infoveillance Study. Journal of Medical Internet Research, 22(10), 1-12. https://doi.org/10.2196/22624

Clark, C., Davila, A., Regis, M., dan Kraus, S. (2020). Predictors of COVID-19 voluntary compliance behaviors: An international investigation. Global Transitions, 2, 76-82. https://doi.org/10.1016/j.glt.2020.06.003

Coombs, W. T., dan Holladay, S. J. (2012). The Handbook of Crisis Communication. Chichester: Blackwell Publishing Ltd.

Goeritman, H. I. N. (2021). Komunikasi Krisis Pemerintah Indonesia di Masa Pandemi Covid-19 melalui Media Sosial. Jurnal IPTEK-KOM, 23(1), 1-19.

Goldstein, D. A. N., dan Wiedemann, J. (2020). Who do you trust? The consequences of political and social trust for public responsiveness to COVID-19 orders. In The Consequences of Political and Social Trust for Public Responsiveness to COVID19 Orders (April 19, 2020).

Guglielmi, S., Dotti Sani, G. M., Molteni, F., Biolcati, F., Chiesi, A. M., Ladini, R., Maraffi, M., Pedrazzani, A., dan Vezzoni, C. (2020). Public acceptability of containment measures during the COVID-19 pandemic in Italy: how institutional confidence and specific political support matter. International Journal of Sociology and Social Policy, 40(9-10), 1069-1085. https://doi.org/10.1108/IJSSP07-2020-0342

Hafner-Fink, M., dan Uhan, S. (2021). Life and Attitudes of Slovenians during the COVID-19 Pandemic: The Problem of Trust. International Journal of Sociology, 51(1), 76-85. https://doi.org/10.1080/00207659.2020.1837480

Hernikawati, D. (2021). Kecenderungan Tanggapan Masyarakat Terhadap Vaksin Sinovac Berdasarkan Lexicon Based Sentiment Analysis The Trend of Public Response to Sinovac Vaccine Based on Lexicon Based Sentiment Analysis. 
Jurnal Ilmu Pengetahuan dan Teknologi Komunikasi, 23(1), 21-31. http://dx.doi.org/10.33169/iptekkom.23.1.2021.21-31

Juaningsih, I. N., Consuello, Y., Tarmidzi, A., dan Nur Irfan, D. (2020). Optimalisasi Kebijakan Pemerintah dalam penanganan Covid-19 terhadap Masyarakat Indonesia. SALAM: Jurnal Sosial dan Budaya Syar-i, 7(6), 509-518. https://doi.org/10.15408/sjsbs.v7i6.15363

Junaedi, F., dan Sukmono, F. G. (2020). University Students Behavior in Searching and Disseminating COVID-19 Online Information. Jurnal ASPIKOM, 5(2), 245. https://doi.org/10.24329/aspikom.v5i2.767

Kamil, I. (2018). Peran Komunikasi Pemerintahan dalam Penanganan Lingkungan Kumuh. Mediator: Jurnal Komunikasi, 11(1), 129-139. https://doi.org/10.29313/mediator.v11i1.3322

Kurniasih, E. P. (2020). Dampak Pandemi Covid 19 Terhadap Penurunan Kesejahteraan Masyarakat Kota Pontianak. Prosiding Seminar Akademik Tahunan Ilmu Ekonomi dan Studi Pembangunan 2020, 277-289.

Limilia, P., dan Pratamawaty, B. B. (2020). Google Trends and Information Seeking Trend of COVID-19 in Indonesia. Jurnal ASPIKOM, 5(2), 188. https://doi.org/10.24329/aspikom.v5i2.741

Mansoor, M. (2021). Citizens' trust in government as a function of good governance and government agency's provision of quality information on social media during COVID-19. Government Information Quarterly, 38(4), 101597. https://doi.org/10.1016/j.giq.2021.101597

Muhardiansyah, Y. (2020). DPT Pilkada Medan 2020 Ditetapkan Sebanyak 1.601.001 Pemilih. merdeka.com. https://www.merdeka.com/politik/dpt-pilkada-medan2020-ditetapkan-sebanyak-1601001-pemilih.html

Murphy, K., Williamson, H., Sargeant, E., dan McCarthy, M. (2020). Why people comply with COVID-19 social distancing restrictions: Self-interest or duty? Australian and New Zealand Journal of Criminology, 53(4), 477-496. https://doi.org/10.1177/0004865820954484

Muslim, M. (2020). Manajemen Stress pada Masa Pandemi Covid-19. Jurnal Manajemen Bisnis, 23(2), 192-201.

Neuman, W. (2014). Social Research Methods: Qualitative and Quantitative Approaches (7 ed.). Pearson Education Ltd.

Rachman, F., Health, S. P.-I. of, dan 2020, undefined. (2020). Analisis Sentimen Pro dan Kontra Masyarakat Indonesia tentang Vaksin COVID-19 pada Media Sosial Twitter. Inohim.Esaunggul.Ac.Id, 8(2), 2655-9129. https://inohim.esaunggul.ac.id/index.php/INO/article/download/223/175

Rengkung, C. I. R., Tampi, G. B., dan Londa, V. Y. (2021). Komunikasi Publik Pemerintah Kota Manado dalam Penanganan Covid-19. JAP, VII(102), 26-36.

Reyes Bernard, N., Basit, A., Sofija, E., Phung, H., Lee, J., Rutherford, S., Sebar, B., Harris, N., Phung, D., dan Wiseman, N. (2021). Analysis of crisis communication by the Prime Minister of Australia during the COVID-19 pandemic. International Journal of Disaster Risk Reduction, 62, 102375. https://doi.org/10.1016/j.ijdrr.2021.102375

Rijal, Darlin, dan Haz, M. (2021). Penerapan Protokol Kesehatan dalam Pelayanan Publik Sebagai Upaya Pencegahan Covid-19 di Kampung Yafdas. Pengabdian: Jurnal Hasil Pengabdian Masyarakat, 2(1), 66-83.

Saleh, A., Rudianto, R., Anshori, A., dan Adhani, A. (2021). Political Communication 
in Medan Regional Head Election during the Covid-19 Pandemic Komunikasi. Jurnal ASPIKOM, 6(1), 197-207. https://doi.org/10.24329/aspikom.v6i1.849

Sood, S., dan Sharma, A. (2020). A moderated-mediation model of fear of illness and subjective psychological well-being during COVID-19 pandemic.

Suciati, P., dan Syafiq, A. (2021). School From Home (SFH): Perjuangan Para Orang Tua Siswa Usia Dini Di Masa Pandemi Covid-19. Jurnal Sosial Humaniora Terapan, $3(2)$, $7-16$. http://journal.vokasi.ui.ac.id/index.php/jsht/article/viewFile/129/91

Sugiyono. (2018). Metode Penelitian Kuantitatif. Bandung: Alfabeta.

Sulistyowati, F., dan Hasanah, N. U. (2021). Strategi Komunikasi Pemerintah Indonesia dalam Penanganan COVID-19 pada Majalah TEMPO Edisi Maret-Juli 2020. JURKOM Jurnal Riset Komunikasi, 4 (2), 198-214. http://jurnalrisetkomunikasi.org/index.php/jrk/article/view/326

Sun, Z., Yang, B., Zhang, R., dan Cheng, X. (2020). Influencing factors of understanding covid-19 risks and coping behaviors among the elderly population. International Journal of Environmental Research and Public Health, 17(16), 116. https://doi.org/10.3390/ijerph17165889

Surahmat, A., Dida, S., Zubair, F., Surahmat, A., Dida, S., dan Zubair, F. (2021). Analysis of the Government's Crisis Communication Strategy Discourse to Defend Covid-19 Analisis Wacana Strategi Komunikasi Krisis Pemerintah Menangani Covid-19. Jurnal Komunikasi, 13(1), 36-53.

Tobroni, F. (2020). Pembatasan Kegiatan Keagamaan dalam Penanganan Covid-19. Jurnal Komunikasi Hukum, 6(2), 369-395. http://repositorio.unan.edu.ni/2986/1/5624.pdf

Tuwu, D., Laksmono, B. S., Huraerah, A., dan Harjudin, L. (2021). Dinamika Kebijakan Penanganan Pandemi COVID-19 Dalam Perspektif Kesejahteraan Sosial. Sosio Konsepsia, 10(2), 97-110. https://doi.org/10.33007/ska.v10i2.2158

Vardavas, C., Odani, S., Nikitara, K., El Banhawi, H., Kyriakos, C., Taylor, L., dan Becuwe, N. (2021). Public perspective on the governmental response, communication and trust in the governmental decisions in mitigating COVID-19 early in the pandemic across the G7 countries. Preventive Medicine Reports, 21, 101252. https://doi.org/10.1016/j.pmedr.2020.101252

Windarsih, A. (2021). Public Communication Conflicts between the Central Government and the DKI Jakarta Government in Handling the Covid-19 Pandemic. 495(ICoSPOLHUM 2020), 62-73. 